\title{
THE DEVELOPMENT OF MANAGEMENT ACCOUNTING SKILLS IN SITUATIONS WHERE PRACTICAL EXPOSURE IS LIMITED: THE PERCEPTIONS OF TRAINING OFFICERS IN SOUTH AFRICA
}

\author{
W. A. Bishop
}

School of Accountancy

Stellenbosch University

Stellenbosch, South Africa

e-mail: abishop@sun.ac.za

\section{ABSTRACT}

Training office auditing firms in South Africa are required by the South African Institute of Chartered Accountants (SAICA) training regulations to provide basic exposure to trainees on management accounting learning outcomes that are covered in theoretical aspects at tertiary education level. The purpose of this article was to determine (1) the ways in which large, medium-sized and small training office auditing firms in South Africa evaluate the competency of trainee accountants in the field of management accounting, (2) to what extent alternative skills transfer methods are used and (3) the perceptions of training officers of the use of simulation as a skills transfer method. These were done to identify learning outcome areas of which skills can already be developed at tertiary level, due to the lack of real-life exposure in practice. It is argued that the responsibility of developing skills of students in areas where practical exposure is limited lies with higher education institutions and not training office auditing firms. A web-based questionnaire was used.

This study showed that simulated training, either in-house, outsourced or a combination of the two, is actively used by a number of training office auditing firms in South Africa in order to assess competency in the field of management accounting where practical exposure through performing actual tasks is limited. Skill development simulated training are therefore proposed to be introduced at tertiary level to enable entry-level trainees to be equipped for practice. The study also revealed that training officers perceive simulation to be effective in the assessment of competency in management accounting residual skills competency areas. Simulation can therefore be seen as a valuable tool to use by higher education institutions in order to transfer skills in management accounting to its students.

The research is valuable to higher education institutions (with enrolled students studying towards becoming registered chartered accountants (CA) in South Africa) and SAICA (that develops the learning outcomes followed by these institutions through its syllabi), because it does not only provide an overview of how skills in management accounting are transferred to trainee accountants, but it also provides opportunities for syllabi re-alignments and simulated training at tertiary level.

Keywords: simulation SAICA, residual skills, competency, management decision making and control, financial management, CA students, management accounting 


\section{INTRODUCTION AND BACKGROUND}

As part of the route to becoming a registered chartered accountant (CA) in South Africa, the South African Institute of Chartered Accountants (SAICA) requires of its members to obtain a SAICA accredited qualification, a Certificate in the Theory of Accounting (CTA) followed by a learnership programme as trainees at registered training offices (SAICA 2017). In this study, "students" refer to future CA's that are still in the process of obtaining their qualifications, whereas "trainees" refer to future CA's that are busy completing their training contract at a training office auditing firm. Training offices must meet the accreditation requirements set out in the SAICA training regulations and be able to deliver the appropriate range, depth and quality of training and experience required to train prospective CA's (SAICA 2016c). During the learnership at the training offices, practical experience ought to be gained by trainees in various areas of the accountancy profession, as stipulated by the training programme of SAICA (SAICA 2015a). These areas are aligned with the areas in which theoretical knowledge are to be obtained through the CTA at tertiary level. The SAICA training regulations stipulate that the programme must be administered by a registered training officer. Among others, trainees are required to receive practical training in accounting and external reporting, auditing and assurance, financial management, management decision making and taxation, which are all areas key to the accounting profession (SAICA 2016b). This training programme includes a list of prescribed competencies to which trainees should be practically exposed during the work in which they are involved (SAICA 2016b). Competencies are skill areas to which trainees need to be exposed and provide evidence that they are competent in these areas. The competency areas are divided into three different skills categories, namely compulsory skills, elective skills and residual skills (SAICA 2015a).

Compulsory skills include competencies in accounting and external reporting, professional conduct, management and leadership, personal attributes and information technology. Furthermore, trainees are required to have advanced experience in these compulsory skills (SAICA 2016c). Besides compulsory skills, advanced experience should also be offered to trainees in at least one of the five prescribed elective skills, which are auditing and assurance, financial management, management decision making and control, taxation, and risk management and governance (SAICA 2016c). In the remaining four elective skills that have not been selected for advanced exposure, trainees are only required to have basic exposure (SAICA 2016c). These are referred to as residual skills (Warffemius, Kruger and Steenkamp 2015). Management accounting skills are regarded as residual skills in auditing firms where students select auditing and assurance as electives. 
After inspecting the entire list of training office auditing firms in South Africa, as obtained in a document directly from SAICA, it was concluded that the majority of training office auditing firms in South Africa, due to the nature of their services being that of auditing and assurance by definition (Joubert, Coetzee and Oberholzer 2009; Barac 2009), select auditing and assurance as the elective skills competency area. Financial management, management decision making and control, taxation, and risk management and governance are as a result selected as the residual skills competency areas. This implies that trainees in auditing firms only have to have basic exposure in these areas. Auditing and assurance are the main service lines for auditing firms and limited services are provided that involve financial management and management decision making and control (Joubert, Coetzee and Oberholzer 2009). As a result, there is limited exposure for trainees in these two residual skills competency areas. These two competency areas are structured around competencies in the field of management accounting. The training programme, however, allows for firms to make use of workplace simulation to provide exposure to trainees in areas where practical exposure is limited (SAICA 2016c). SAICA also provided a guideline on what simulations entail and the approach that needs to be followed by training officers. The ways in which auditing firms in South Africa evaluate competency in the field of management accounting and the extent to which simulations are used as a replacement tool for practical exposure through actual tasks were evaluated in this study. This study further suggests that skill development that is not obtained through practical exposure at training office auditing firms, should rather be developed at tertiary level through the same replacement tools currently used by these firms.

\section{RESEARCH PROBLEM AND OBJECTIVE}

It has long been argued that a gap exists between the theoretical knowledge students studying towards becoming CAs of South Africa (CA[SA]) gain while studying towards obtaining their degrees/diplomas and the skills that are required for first-year trainees to be equipped for practice (Van Romburgh and Van der Merwe 2015). The gap referred to by Van Romburgh and Van der Merwe (2015) is attributable to the fact that students are not exposed to practical tasks at universities. It has been suggested that this gap be filled by providing first-year trainees with more practical exposure before entering practice. A study by (Rudman and Kruger (2014) concluded that a group case study in the field of management accounting at university level assisted students in gaining the skills to work in groups and practically develop the competency to prepare a business plan. For the purpose of this article, management accounting is defined as functions performed in a business that involve the compilation and analyses of budgets, the analysis of an entity's financial situation and the analyses of business valuations, as 
recommended by SAICA (2015a).

The skills gap referred to above is illustrated in Figure 1 below (refer to "Skills gap"):

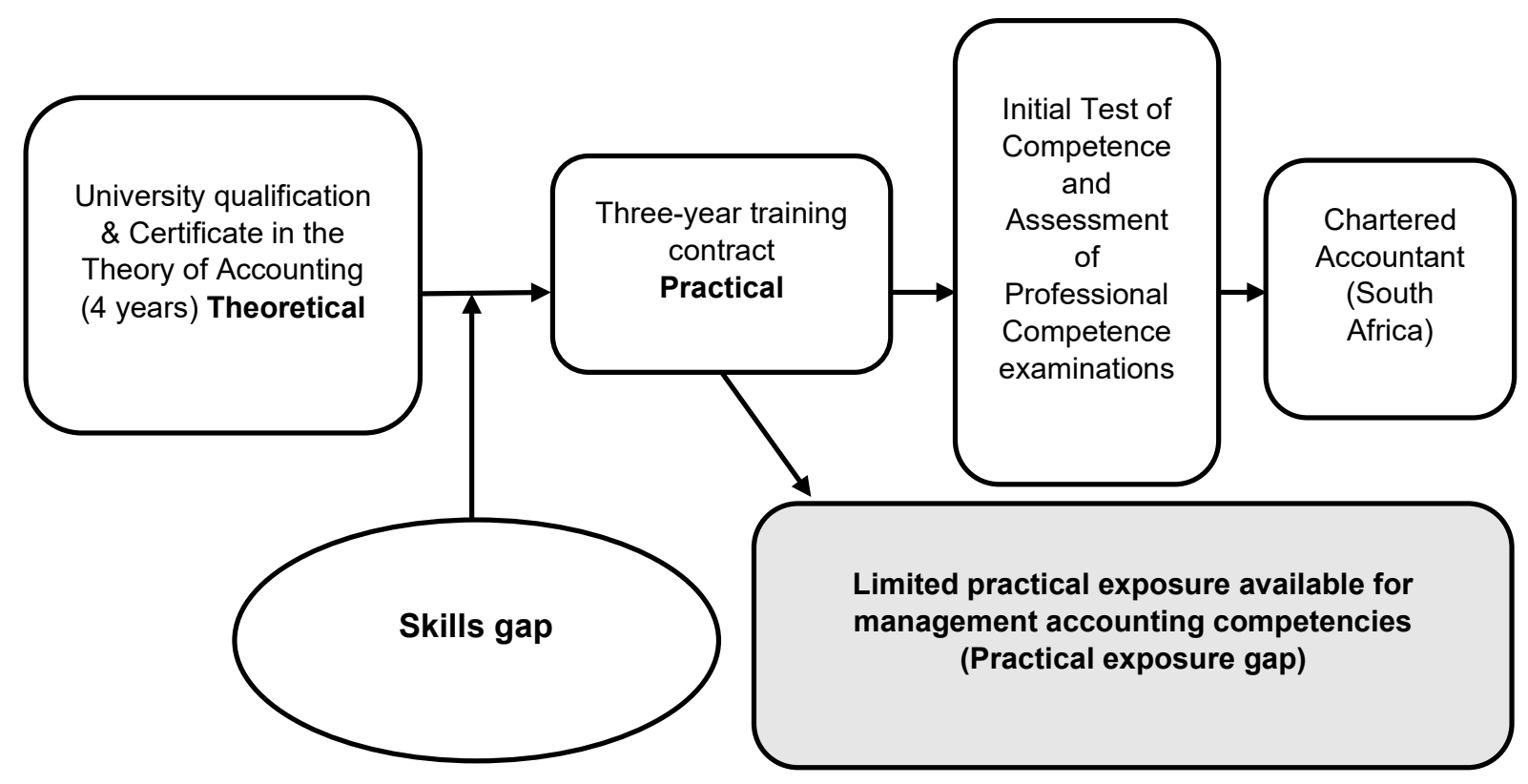

Figure 1: Practical exposure gap (SAICA 2016a)

The skills gap (Figure 1) has been researched previously (Rudman and Terblanche 2012; Schutte 2013). In both these studies it was found that the perception lies with students that practical application in the form of real-work experience is an important requirement in order to reflect on theoretical knowledge.

During the three-year training contract, trainees are required to gain practical experience in the various competency areas required by the SAICA training programme. As discussed previously, auditing and assurance services are generally the main service lines for auditing firms, previously better known as TIPP (training inside public practice), and limited services are provided that involve management accounting (Joubert, Coetzee and Oberholzer 2009). As a result, trainees with training contracts at auditing firms have limited exposure in the field of management accounting (refer to "Practical exposure gap" in Figure 1, identified as the focus of this article). This practical exposure gap is however addressed by the SAICA training programme, as it allows for firms to make use of workplace simulation to provide exposure to trainees in areas where practical exposure is limited (SAICA 2016c). Trainees training outside public practice, in other words not at auditing firms, have more exposure to management accounting, as their duties involve performing management accounting tasks. This study therefore focused on the transfer of management accounting skills of trainees training inside 
public practice. The objective of this research was to determine:

- whether training office auditing firms in South Africa provide practical exposure to their trainees in the field of management accounting, specifically in the residual skills competency areas of financial management and management decision making and control and whether exposure differs between the different sizes of auditing firms;

- whether training office auditing firms in South Africa make use of workplace simulation, as a skill transferring tool, to evaluate competency where practical exposure is limited in order to address the practical exposure gap in the residual skills competency areas of specifically financial management and management decision making and control; and

- if simulation is used as an alternative to practical exposure, whether the training officers of training office auditing firms perceive these simulations to be sufficient in providing basic exposure to their trainees.

This research was done to evaluate mechanisms used by training office auditing firms to transfer management accounting skills to trainees. The research directly addressed the practical exposure gap (Figure 1) and is topical and relevant to higher education, as it can assist universities in developing syllabus areas where skills can be developed to assist students to be equipped for practice. For this purpose, the study focused specifically on the management accounting residual skills competency areas where practical exposure in practice is assumed to be limited, due to the nature of services rendered by auditing firms in general (i.e. auditing, taxation, consulting and financial accounting). The research questions included the following:

- For each residual skills competency area in financial management and management decision making and control, what mechanism is used to evaluate competency?

- Where simulation is used as a skill transferring mechanism, do training officers perceive these simulations to be effective in the evaluation of whether a trainee has basic exposure in residual skills competency areas?

- Do training officers consider simulation sufficient to conclude on the competency of a trainee, or should it be combined with performing actual tasks?

- Do training officers perceive one simulation per residual skills competency area sufficient to conclude on the competency of a trainee in that competency area? 


\section{LITERATURE REVIEW}

\section{Practical experience requirements of the chartered accountancy profession worldwide}

Part of the route to becoming a CA in South Africa involves being exposed to practical work. This is similar to guidelines followed in other countries. In the United Kingdom, the route to becoming a CA includes, over and above practical experience, the completion of a test of professional expertise. This entails that work be done on a multi-disciplinary case study whereby professional advice is required to be provided in real-life scenarios (ICAS 2016).

In Australia and New Zealand, practical experience is also required in real-life situations. Chartered Accountants Australia and New Zealand (ANZ) is a member of the International Federation of Accountants (IFAC), which prescribes logged practical experience in the IFAC framework (Chartered Accountants ANZ 2015). In the IFAC practice statement, simulation as a tool is allowed as supplement for practical exposure. In this statement, simulation includes work-based projects, "in-tray" types of activities, role play and even case studies (IFAC 2007).

As per the Chartered Professional Accountants of Canada (CPA) registration requirements, practical experience is listed as a requirement in the process of becoming a registered chartered professional accountant. The CPA competency map lists simulation as an evaluation tool that can be used to assist in the development of competencies of candidates (CPA 2014).

\section{Importance of practical exposure in management accounting}

Management accounting skills play an important role in managing businesses. Francis and Minchington (1999) argue that management accountants are seen as business advisors. In a study on the perceptions of skills requirements of trainee accountants, it was concluded that the perception of auditing training officers was that skills in management accounting are only of reasonable importance (Barac 2009). The researchers agree that being in the auditing sector, management accounting skills play a smaller role; however, when qualified as a CA and practising outside the auditing industry, management accounting skills are valuable skills to have in order to effectively run a business. As previously mentioned, the SAICA training programme requires of trainees to have only basic exposure in the field of management accounting when the financial management and management decision-making and control competency areas are selected as residual skills categories (SAICA 2016c), which is evident from the literature. A study on the gap between theoretical knowledge and competency concluded that small and medium-sized accounting firms in South Africa require of trainees to 
be competent on a moderate level in management accounting and financial management skills (Schutte 2013). This implies that exposure in management accounting is important and that not all firms provide equal practical experience opportunities, which creates the need to potentially have this addressed at tertiary level. A study on the teaching of pervasive skills to accounting students at South African universities showed that heads of departments perceive that certain pervasive skills required by the SAICA training programme are best achieved in the real-world, practical workplace, rather than in the theoretical studies of students (Barac and Plessis 2014). This implies that practical exposure in the real-world is important and if real-life exposure is limited, it could be addressed at tertiary level through replacement tools such as simulation.

\section{Simulation as a recognised replacement tool for practical exposure in South Africa}

From literature discussed in Section 3.1, it is clear that simulation is a valuable skill transferring tool to evaluate competency where practical exposure is limited. The definition of simulation varies within different literature due to its different uses in different fields. In the field of accounting, simulations are seen as activities that are used to develop professional and other skills by simulating real-life scenarios in the form of inter alia role-playing and case studies (Dellaportas and Hassall 2013; IFAC 2007; Van der Merwe 2013). The SAICA guidelines on the use of simulations define simulations as learning activities that replace practical experience (SAICA 2015b). Case studies are regularly used by international companies to transfer certain skills (Keevy 2016). A recent study, however, concluded that case studies are used less by South African accounting academics to evaluate competency (Keevy 2016), whereas other researchers recommended simulations in accounting education in recent years (Steenkamp and Von Wielligh 2011; Van der Merwe 2013).

The SAICA guidelines explain that the use of simulation for the purpose of evaluating competency in terms of the SAICA competencies should be linked to the specific required competency and demonstrate effectively what is expected of that competency. The SAICA guidelines on simulations require that simulations also include an assessment using the same ratings as what would normally be used to evaluate practical experience (SAICA 2015b). As per the SAICA training programme, simulations may be used on tasks to a maximum level of 10 per cent of the total number of compulsory or elective skills competency areas and to a maximum of 50 per cent of the total number of residual tasks (SAICA 2015a).

\section{Appropriateness of simulation as a learning tool in management accounting}

In a study conducted by Rudman (2013), it was concluded that simulation is an appropriate tool 
to use in the field of management accounting. The study focused on the responses of students at Stellenbosch University who were studying a programme, accredited by SAICA towards the $\mathrm{CA}(\mathrm{SA})$ designation. A simulation was done in the form of compiling a business plan for a reallife company, which falls under one of the learning outcomes of the SAICA learning plan as part of management accounting. From this study, it was concluded that students benefited from the simulation and that it supplied them with the skill of developing a business plan (Rudman 2013). This is supported by another study by Lu, Hallinger and Showanasai (2014) on students' perceptions of simulation. In this study, it was concluded that students perceive simulation as an effective learning tool for learning management subjects. Wellington, Faria, Hutchinson and Gowing (2011) concluded that simulation improved students' knowledge in management accounting and finance principles in their study on the use of a marketing simulation game to evaluate knowledge in management accounting skills. Another study conducted on the use of a business simulation to develop certain professional skills in accountancy students in South Africa concluded that in general, students perceived an integrated accountancy simulation as a valuable development tool (Van der Merwe 2013).

A study conducted in South Africa on the usefulness of an audit simulation to evaluate competency showed that trainee accountants were of the perception that simulations enhanced their competency levels in performing substantive procedures (Steenkamp and Von Wielligh 2011; Van der Merwe 2013). De Villiers (2015) recently concluded that the development of a simulation instrument in specifically audit education is invaluable to learning. A study by Viviers, Fouché and Reitsma (2016), however, revealed that active learning methods are developed on all areas of financial accounting, auditing, managerial accounting and finance, but none on taxation. Consequently, an educational game was developed to evaluate taxationrelated competencies. This study concluded that students perceive an educational game (as a form of simulation) to be successful in encouraging them to develop pervasive skills required by SAICA's competency framework.

The above-mentioned studies all focused on the perspectives of students and whether they believe that simulation contributes towards obtaining certain skills. All simulations included in these studies were done at universities or business schools as part of learning techniques to address the skills gap, as shown in Figure 1. Making use of simulation is seen as a valuable tool to develop business skills such as leadership and effective communication (Rudman and Kruger 2014). Developing skills by simulating specific real-life tasks is a powerful learning tool to achieve learning outcomes (Dellaportas and Hassall 2013). It is therefore clear from the literature review that simulation plays an invaluable role in the development of skills for individuals studying towards the accountancy profession and that the wider use of simulation 
to address other areas in management accounting can only be beneficial and valuable.

In a study by Barac (2009) it was concluded that training officers in South Africa were of the opinion that entry-level trainees lack certain analytical skills. Analytical skills are important skills for trainees in order to perform certain financial management and management decisionmaking and control tasks (SAICA 2015a). Examples of analytical skills in management accounting required in the SAICA competency framework are as follows (SAICA 2015a):

- Analysing an entity's financial situation by means of ratio analysis, trend analysis and cash flow analysis

- Performing a sensitivity analysis on business valuations

- $\quad$ Performing sensitivity analyses on varying key assumptions made in the preparation of budgets

- Analysing budget variances.

A lack of skills of entry-level trainees will place a bigger responsibility on universities in terms of the development of students to be equipped for practice. Simulation is one type of learning tool that is available to develop these skills (SAICA 2016c). This study focused on the perspective of training officers regarding whether they believe that simulation contributes to skills development. The ways in which training office auditing firms evaluate competency in management accounting and the perception of training officers of using simulation as a learning tool were researched by means of a web-based questionnaire.

\section{RESEARCH METHODOLOGY}

\section{Research design and method}

The purpose of this study was to determine to what degree practical exposure in management accounting is provided to trainees in South Africa studying towards becoming CA's and to identify areas of limited practical exposure that ought to be addressed at tertiary level. An empirical research methodology was decided upon with a short literature review to provide more background on the research questions included. Web-based questionnaires were distributed to SAICA-registered training officers of training office auditing firms in South Africa. The SAICA training programme implementation guide provides guidelines and suggestion to specifically training officers on ways to provide trainees with exposure to practical training requirements (SAICA 2016b). Training officers are responsible for the 
training programme of training offices, therefore the training officers themselves were surveyed to (1) gain information on the ways in which they evaluate competencies in residual skill areas at their respective training offices and (2) obtain the perceptions of training officers of simulation as an evaluation tool. As training officers are responsible for the training programmes (SAICA 2016c), they are also seen to be the individuals at training offices with the most knowledge of the different required SAICA learning plan outcomes and training programme and who will understand the depth of the competencies covered in this study.

\section{Data collection, capturing and validation}

The target population of the current study was training officers of training office auditing firms in South Africa, with auditing and assurance as their elective skills competency area and financial management and management decision making and control as their residual skills competency areas. The full list of these training officers was obtained directly from SAICA. A web-based research questionnaire was developed using the SUrveys software program available to researchers of Stellenbosch University. Questionnaires were sent in electronic format via the SUrveys software program to all training officers of SAICA-registered training offices in South Africa that have auditing and assurance as their elective skills competency area and financial management and management decision making and control as residual skills competency areas. All electronic links had an original respondent ID number to ensure that questionnaires can only be completed once by the respective training officer. Links were also only sent to one training officer registered per training office to ensure that results from the same training office are not duplicated.

The questionnaire consisted of two sections to test the different research objectives of this study. The first part of the questionnaire consisted of pre-designed categorical questions (practical exposure through actual tasks, in-house simulation, outsourced simulation, other forms of evaluation) for each residual skill area from which training officers had to select the evaluation method that is used at their training office auditing firm to evaluate the competencies of their trainees. An open-ended option was also available to training officers if they selected "Other forms of evaluation". The second part of the questionnaire, which tested the perceptions of training officers of the use of simulations as an evaluation tool, consisted of categorical questions in which the training officers had to indicate whether they perceive simulations to be effective and sufficient in the evaluation of residual skill competencies. Effectiveness of using simulation as a tool for evaluation of residual skill areas was defined as: "Does a simulation provide the required level of exposure to trainees to enable training officers to conclude on whether a trainee is competent in a certain skill area?" Sufficiency was defined as: "Does a 
simulation, as the only form of exposure, provide trainees with enough exposure to enable training officers to conclude on whether a trainee is competent in a certain skill area?"

\section{Data analysis}

The data were analysed and summarised by an independent centre for statistical consultation in accordance with the size of the training office auditing firm. Standard frequency and contingency tables were received from the centre on which results were based. The significance of the results was based on normal p-values and by conducting Chi-square tests.

The response rate percentage was calculated on the number of questionnaires sent out but also in terms of the number of trainees represented by the training office, as the first research objective focused on how trainees' competencies in residual skills are evaluated in South Africa. It was therefore important to consider the data coverage in respect of all trainees in South Africa (i.e. how the trainees' competencies are evaluated).

\section{Response rate and respondent profile}

There were 574 training officers in South Africa with auditing and assurance as their training office auditing firm's elective skills competency area at the time that the questionnaires were sent out. A total of 85 training officers from the 574 responded. For a population of 574 , a 95 per cent confidence level and a 10 per cent margin of error, a sample size of at least 83 ought to be selected using a statistical sample calculation (Lincoln University 2006). A response rate of 85 was therefore an acceptable number of respondents (Lincoln University 2006). Although this response rate still appears to be low, it represents information on how the competencies of 2211 of 8902 of South Africa's trainees studying towards becoming a CA(SA) are evaluated.

SAICA typically divides training offices into the categories of large, medium-sized and small. The SAICA-required competency levels of these firms are the same; however, client size, client profile and the amount of practical exposure may differ between the different types of firms (Joubert, Coetzee and Oberholzer 2009; Van Romburgh and Van der Merwe 2015). Clients of small firms typically include individuals, entrepreneurs and local retailers and manufacturers (Joubert, Coetzee and Oberholzer 2009). Medium-sized firms generally have more or less the same client types as small firms, but may have more offices and the capacity to serve larger clients (Joubert, Coetzee and Oberholzer 2009). Large firms are classified as such based on their levels of income (Coetzee and Oberholzer 2009). These classifications are done annually by SAICA in accordance with strict guidelines. The SAICA categories were directly received from SAICA in accordance with the training offices' registered information and not from the training officers themselves, eliminating the risk of training officers incorrectly 
indicating the firm size. The response rate of 85 out of 574 training officers was therefore further divided into these pre-assigned SAICA categories, as shown in Table 1.

Table 1: Response rate of training officers

\begin{tabular}{|l|c|c|}
\hline & $\begin{array}{c}\text { Number of registered training } \\
\text { officers }\end{array}$ & $\begin{array}{c}\text { Number of training officers } \\
\text { responded }\end{array}$ \\
\hline Large firms & 10 & 3 \\
\hline Medium-sized firms & 26 & 14 \\
\hline Small firms & 538 & 68 \\
\hline Total & $\mathbf{5 7 4}$ & $\mathbf{8 5}$ \\
\hline
\end{tabular}

The responding training officers represented training office auditing firms for 2211 out of 8902 of the active audit trainees in South Africa, as indicated in Table 2.

Table 2: Trainee representation of responding training officers

\begin{tabular}{|l|c|c|}
\hline & $\begin{array}{c}\text { Number of active trainees in training } \\
\text { offices }\end{array}$ & $\begin{array}{c}\text { Number of active trainees in offices } \\
\text { of responding officers }\end{array}$ \\
\hline Large firms & 3197 & 1156 \\
\hline Medium-sized firms & 1612 & 445 \\
\hline Small firms & 4093 & 610 \\
\hline Total & $\mathbf{8 9 0 2}$ & $\mathbf{2 ~ 2 1 1}$ \\
\hline
\end{tabular}

As the response rate still appears low, it should be noted that it is in line with other related studies that had response rates similar to this study and that were cited in the literature review of this study. A response rate of only 16.9 per cent of audit firms in Gauteng was achieved in a study in which skills shortages were identified among first-year trainee accountants in South Africa (Van Romburgh and Van der Merwe 2015). Another study by SAICA for a needs analysis report had a response rate of 14.5 per cent (Van Romburgh and Van der Merwe 2015). A response rate of only 8.5 per cent (296 of 3476 employers that had training contracts with the Chartered Institute of Management Accountants students) was received in a study in which the expectation gap between education and practice of management accountants was assessed (Francis and Minchington 1999).

The total response rate of 85 out of 574 training officers was low mainly due to the response rate of the smaller firms, which on average have the lowest number of trainees per firm, many with only one active trainee. The overall response rate of only the large and mediumsized auditing firms was 17 out of 36 officers, which is a much higher response rate. It was however decided to still include the small firms in the analyses, as it increased the number of responses with 63 and because the residual skills competency requirements for large and small firms are the same. Small auditing firms are also very similar in nature due to the services that 
they provide and the type of client bases (Joubert, Coetzee and Oberholzer 2009), which strengthen the argument that similar evaluation techniques are used by most small firms.

\section{EMPIRICAL RESEARCH FINDINGS}

The first part of the research questionnaire asked of training officers to indicate, on behalf of training office auditing firms, how competencies in the residual skills competency areas of financial management and management decision making and control are obtained by their trainees. At the time of the study there were many external organisations offering training office auditing firms the opportunity of outsourcing simulation to them. Therefore, the three ways in which competencies of trainees are evaluated are by providing practical exposure to the completion of actual on-the-job tasks, providing in-house simulation or making use of external contractors and outsourcing simulation.

All management accounting-related competencies are numbered with the prefix FM for financial management competencies and MD for management decision-making and control competencies. The prefix R stands for residual skills. Management accounting competencies included in this study are further discussed below.

\section{Competencies in financial management}

- As per this first competency, number $\mathrm{FM}(\mathrm{R}) 1$, trainees/students are required to be able to analyse an entity's financial situation. This can be done through financial analysis, ratio analysis, trend analysis and cash flow analysis (SAICA 2015a).

- $\quad \mathrm{FM}(\mathrm{R}) 2$ requires of trainees/students to monitor cash flow. Cash flow forecasts are to be prepared and evaluated and possible cash shortfalls should be identified. Possible action plans also need to be recommended (SAICA 2015a).

- $\quad \mathrm{FM}(\mathrm{R}) 3$ requires of trainees/students to evaluate an entity's current working capital position and recommend improvements (SAICA 2015a).

- $\quad \mathrm{FM}(\mathrm{R}) 4$ requires of trainees/students to evaluate the financial implications of investment decisions by making use of capital budgeting techniques (SAICA 2015a).

- $\quad \mathrm{FM}(\mathrm{R}) 5$ requires the calculation and evaluation of a reasonable range of values for a business by making use of various valuation techniques. Trainees/students also need to be able to identify factors and external influences that will impact the calculated values (SAICA 2015a). 


\section{Competencies in management decision making and control}

- $\quad \mathrm{MD}(\mathrm{R}) 1$ requires of trainees/students to identify and evaluate an entity's key financial and non-financial performance indicators and to evaluate performance-measurement methods (SAICA 2015a).

- $\quad \mathrm{MD}(\mathrm{R}) 2$ requires the preparation of budgets and sensitivity analyses on varying key assumptions to document a range of possible outcomes (SAICA 2015a).

- $\quad \mathrm{MD}(\mathrm{R}) 3$ requires the analysis and interpretation of budget variances. Actual performances are to be compared to budgeted expectations and reasons should be provided for variances. Recommendations should also be made on how to address identified variances.

\section{Ways in which competencies are achieved}

The total results from the training officers $(n=85)$ who participated in this study ("participating training officers") are listed in Table 3.

Table 3: Competency obtainment by trainees in 85 of the training office auditing firms in South Africa

\begin{tabular}{|c|c|c|c|c|}
\hline \multirow[b]{2}{*}{$\begin{array}{c}\text { Competency } \\
\text { number }\end{array}$} & \multicolumn{4}{|c|}{ Ways in which competencies of trainees are evaluated } \\
\hline & $\begin{array}{l}\text { Practical } \\
\text { exposure through } \\
\text { actual tasks }\end{array}$ & $\begin{array}{l}\text { In-house } \\
\text { simulation }\end{array}$ & $\begin{array}{l}\text { Outsourced } \\
\text { simulation }\end{array}$ & $\begin{array}{l}\text { Other forms of } \\
\text { evaluation }\end{array}$ \\
\hline \multicolumn{5}{|c|}{ Financial management $(n=85)$} \\
\hline $\mathrm{FM}(\mathrm{R}) 1$ & 53 & 12 & 18 & 2 \\
\hline $\mathrm{FM}(\mathrm{R}) 2$ & 34 & 23 & 26 & 2 \\
\hline $\mathrm{FM}(\mathrm{R}) 3$ & 48 & 14 & 21 & 2 \\
\hline $\mathrm{FM}(\mathrm{R}) 4$ & 16 & 34 & 33 & 2 \\
\hline $\mathrm{FM}(\mathrm{R}) 5$ & 19 & 34 & 30 & 2 \\
\hline \multicolumn{5}{|c|}{ Management decision making and control $(n=85)$} \\
\hline $\mathrm{MD}(\mathrm{R}) 1$ & 44 & 23 & 16 & 2 \\
\hline $\mathrm{MD}(\mathrm{R}) 2$ & 39 & 22 & 22 & 2 \\
\hline$M D(R) 3$ & 44 & 18 & 21 & 2 \\
\hline
\end{tabular}

From the Table 3 it is clear that, from the feedback received from the participating training officers, there is a wide spread between the ways in which training office auditing firms in South Africa evaluate competency in management accounting skills. Practical exposure, inhouse simulation and outsourced simulations are all used for different management accounting competency areas, which is in line with literature reviewed. Training officers who indicated that other forms of evaluation are used, clarified through open-ended feedback that a combination of practical exposure and outsourced simulations is used to evaluate competency. Practical exposure is limited in the areas of cash flow monitoring ( $\mathrm{FM}(\mathrm{R}) 2)$, capital budgeting techniques $(\mathrm{FM}(\mathrm{R}) 4)$, business valuations $(\mathrm{FM}(\mathrm{R}) 5)$ and budget preparation and sensitivity 
analyses $(M D(R) 2$, where only 39 out of the 85 participating training officers indicated that practical exposure in actual tasks is available. Skills development in these areas can thus already be incorporated through other teaching skills such as simulation at tertiary level. This was anticipated by the literature reviewed.

The ways in which management accounting residual skills competencies are evaluated were further analysed and listed separately for large, medium-sized and small training office auditing firms, due to the level of practical exposure available differing in terms of the size of the firm.

\section{Large training office auditing firms}

Table 4 illustrates, from feedback received from the participating training officers, how competencies of trainees are evaluated at three of the large training office auditing firms in South Africa.

Table 4: Competency evaluation of trainees in three large training office auditing firms in South Africa

\begin{tabular}{|c|c|c|c|c|}
\hline \multirow[b]{2}{*}{$\begin{array}{c}\text { Competency } \\
\text { number }\end{array}$} & \multicolumn{4}{|c|}{ Ways in which competencies of trainees are evaluated } \\
\hline & $\begin{array}{l}\text { Practical } \\
\text { exposure through } \\
\text { actual tasks }\end{array}$ & $\begin{array}{l}\text { In-house } \\
\text { simulation }\end{array}$ & $\begin{array}{l}\text { Outsourced } \\
\text { simulation }\end{array}$ & $\begin{array}{l}\text { Other forms of } \\
\text { evaluation }\end{array}$ \\
\hline \multicolumn{5}{|c|}{ Financial management $(n=3)$} \\
\hline $\mathrm{FM}(\mathrm{R}) 1$ & 3 & 0 & 0 & 0 \\
\hline $\mathrm{FM}(\mathrm{R}) 2$ & 1 & 2 & 0 & 0 \\
\hline $\mathrm{FM}(\mathrm{R}) 3$ & 2 & 1 & 0 & 0 \\
\hline $\mathrm{FM}(\mathrm{R}) 4$ & 0 & 3 & 0 & 0 \\
\hline $\mathrm{FM}(\mathrm{R}) 5$ & 0 & 3 & 0 & 0 \\
\hline \multicolumn{5}{|c|}{ Management decision making and control $(n=3)$} \\
\hline $\mathrm{MD}(\mathrm{R}) 1$ & 2 & 1 & 0 & 0 \\
\hline $\mathrm{MD}(\mathrm{R}) 2$ & 3 & 0 & 0 & 0 \\
\hline$M D(R) 3$ & 3 & 0 & 0 & 0 \\
\hline
\end{tabular}

From Table 4 it is clear that the three large training office auditing firms are making use of either practical exposure or in-house simulation to evaluate competencies of trainees. In-house simulation is used by some firms for evaluating skills in cash flow monitoring, current working capital position evaluations and the evaluation of key financial and non-financial performance indicators. Training officers of all large firms that took part in this study indicated that simulation are used to evaluate competencies in business valuation and skills relating to the evaluation of financial implications of investment decisions. This shows that simulation is a tool that can also be used by tertiary institutions to develop skills of university students in abovementioned areas. 


\section{Medium-sized training office auditing firms}

Table 5 illustrates, from the view of the participating training officers, how competencies are achieved by 14 of the medium-sized training office auditing firms in South Africa.

Table 5: Competency evaluation of trainees in 14 medium-sized training office auditing firms in South Africa

\begin{tabular}{|c|c|c|c|c|}
\hline \multirow[b]{2}{*}{$\begin{array}{c}\text { Competency } \\
\text { number }\end{array}$} & \multicolumn{4}{|c|}{ Ways in which competencies of trainees are evaluated } \\
\hline & $\begin{array}{l}\text { Practical } \\
\text { exposure through } \\
\text { actual tasks }\end{array}$ & $\begin{array}{l}\text { In-house } \\
\text { simulation }\end{array}$ & $\begin{array}{c}\text { Outsourced } \\
\text { simulation }\end{array}$ & $\begin{array}{l}\text { Other forms of } \\
\text { evaluation }\end{array}$ \\
\hline \multicolumn{5}{|c|}{ Financial management $(n=14)$} \\
\hline $\mathrm{FM}(\mathrm{R}) 1$ & 6 & 5 & 3 & 0 \\
\hline $\mathrm{FM}(\mathrm{R}) 2$ & 2 & 9 & 3 & 0 \\
\hline$F M(R) 3$ & 7 & 4 & 3 & 0 \\
\hline $\mathrm{FM}(\mathrm{R}) 4$ & 0 & 11 & 3 & 0 \\
\hline $\mathrm{FM}(\mathrm{R}) 5$ & 0 & 11 & 3 & 0 \\
\hline \multicolumn{5}{|c|}{ Management decision making and control $(n=14)$} \\
\hline $\mathrm{MD}(\mathrm{R}) 1$ & 5 & 7 & 2 & 0 \\
\hline $\mathrm{MD}(\mathrm{R}) 2$ & 6 & 6 & 2 & 0 \\
\hline MD(R)3 & 7 & 5 & 2 & 0 \\
\hline
\end{tabular}

From Table 5 it can be seen that more than 7 out of the 14 participating training officers of medium-sized auditing firms indicated that they are making use of simulation provided by external service providers to assess competency in financial management skill areas $\mathrm{FM}(\mathrm{R}) 1$, $\mathrm{FM}(\mathrm{R}) 2, \mathrm{FM}(\mathrm{R}) 4$ and $\mathrm{FM}(\mathrm{R}) 5$, whereas 7 out of the 14 officers indicated that practical exposure in evaluating an entity's current working capital position (FM(R)3 is available. Three of the 14 firms make use of outsourced simulation to evaluate competency in all financial management skill areas, while only two of the 14 firms use external service providers for assessing competency in management, decision-making and control skill areas through simulation.

From the feedback received from the training officers, the 14 medium-sized training office auditing firms overall also do not make use of practical exposure in the same areas as the three large auditing firms. These medium-sized firms are making more use of simulation than the three large auditing firms. Residual skills in management accounting are generally transferred by means of simulation, either in-house or outsourced. This further shows that simulation is a tool that can also be used by tertiary institutions to develop skills of university students in abovementioned areas.

\section{Small training office auditing firms}

Table 6 illustrates how, from the feedback received from the participating training officers, 
competencies are evaluated by 68 of the small training office auditing firms in South Africa.

Table 6: Competency evaluation of trainees in 68 small training office auditing firms in South Africa

\begin{tabular}{|c|c|c|c|c|}
\hline \multirow[b]{2}{*}{$\begin{array}{c}\text { Competency } \\
\text { number }\end{array}$} & \multicolumn{4}{|c|}{ Ways in which competencies of trainees are evaluated } \\
\hline & $\begin{array}{l}\text { Practical } \\
\text { exposure through } \\
\text { actual tasks }\end{array}$ & $\begin{array}{l}\text { In-house } \\
\text { simulation }\end{array}$ & $\begin{array}{l}\text { Outsourced } \\
\text { simulation }\end{array}$ & $\begin{array}{l}\text { Other forms of } \\
\text { evaluation }\end{array}$ \\
\hline \multicolumn{5}{|c|}{ Financial management $(n=68)$} \\
\hline $\mathrm{FM}(\mathrm{R}) 1$ & 44 & 7 & 15 & 2 \\
\hline $\mathrm{FM}(\mathrm{R}) 2$ & 31 & 12 & 23 & 2 \\
\hline $\mathrm{FM}(\mathrm{R}) 3$ & 39 & 9 & 18 & 2 \\
\hline $\mathrm{FM}(\mathrm{R}) 4$ & 16 & 20 & 30 & 2 \\
\hline $\mathrm{FM}(\mathrm{R}) 5$ & 19 & 20 & 27 & 2 \\
\hline \multicolumn{5}{|c|}{ Management decision making and control $(n=68)$} \\
\hline $\mathrm{MD}(\mathrm{R}) 1$ & 37 & 15 & 14 & 2 \\
\hline $\mathrm{MD}(\mathrm{R}) 2$ & 30 & 16 & 20 & 2 \\
\hline $\mathrm{MD}(\mathrm{R}) 3$ & 34 & 13 & 19 & 2 \\
\hline
\end{tabular}

It is clear from Table 6 that the 68 participating training officers of small training office auditing firms indicated that they make use of practical exposure, in-house simulation and outsourced simulation to evaluate the competency of trainees in residual skill areas. Practical exposure in terms of financial statement analysis, current working capital position evaluations and the evaluation of key financial and non-financial performance indicators is provided by more than 34 out of the 68 small firms. Fewer than 20 of these small firms do not provide practical exposure in terms of business valuations and evaluations of investment decisions. This shows that simulation is a tool that can also be used by tertiary institutions to develop skills of university students in areas where practical exposure is limited.

\section{Other empirical findings}

The statistical results indicated that a relationship exists between the size of the training office auditing firm and the ways in which competency is evaluated in monitoring cash flow (FM(R)2). A highly significant number of training officers of large and medium-sized training office auditing firms $(82.35 \%$ with $\mathrm{p}<0.05$ and Chi-square $(\mathrm{df}=6)$ of 15.93$)$ indicated that simulations (either in-house or outsourced) are used for evaluation in this skill area, where-as only 54.44 per cent of small firms make use of simulation for this purpose. Hence, the larger the firm, the higher the probability that the firm will make use of simulation as an evaluation technique in evaluating competency in the monitoring of cash flow.

A highly significant number of training officers of large and medium-sized training office auditing firms $(82.35 \%$ with $\mathrm{p}<0.05$ and Chi-square $(\mathrm{df}=6)$ of 20.19$)$ indicated that in-house 
simulation is used to evaluate competencies in the evaluation of financial implications of investment decisions by making use of the capital budgeting techniques skill area $(\mathrm{FM}(\mathrm{R}) 4$, whereas only 29.41 per cent of small firms make use of in-house simulation. Smaller firms tend to make use of outsourced simulation (44.12\%) and practical exposure $(23.53 \%)$.

A highly significant number of training officers of large and medium-sized training office auditing firms $(82.35 \%$ with $\mathrm{p}<0.05$ and Chi-square $(\mathrm{df}=6)$ of 20.79$)$ also indicated that inhouse simulation is used to evaluate competencies in the business valuation skill area $(\mathrm{FM}(\mathrm{R}) 5$, where-as only 29.41 per cent of small firms make use of in-house simulation. Smaller firms tend to make use of outsourced simulation (39.71\%) and practical exposure (27.94\%).

These results show that simulation is a tool that is widely used in practice and can also be used by tertiary institutions to develop skills of university students in areas where practical exposure is limited.

\section{Simulation as an evaluation tool where practical exposure through actual tasks is limited}

The participating training officers were asked about their opinions on the statements listed in Table 7, of using simulation as a tool to evaluate competency in management accounting residual skills competency areas.

Table 7: Summary of opinions of responding training officers on simulations

\begin{tabular}{|l|c|c|}
\hline \multicolumn{1}{c|}{ Opinion } & $\begin{array}{c}\text { N of responding training } \\
\text { officers agreeing with } \\
\text { opinion }\end{array}$ & $\begin{array}{c}94 \\
\begin{array}{l}\text { Simulation is an effective tool to use in the evaluation of whether a } \\
\text { trainee has basic exposure in residual skills competency areas }\end{array}\end{array}$ \\
\hline $\begin{array}{l}\text { Simulation is a sufficient tool to use to conclude on the competency } \\
\text { level of a trainee in that competency area }\end{array}$ & 83 & 83 \\
\hline $\begin{array}{l}\text { One simulation per residual skills competency area is sufficient to } \\
\text { conclude on the competency level of a trainee in that competency area }\end{array}$ & 77 & 36 \\
\hline
\end{tabular}

\section{Perception of training officers of the usefulness of using simulation as an evaluation tool}

The participating training officers were asked whether they perceive simulation as an effective tool to use in evaluating whether a trainee has sufficient experience in residual skills competency areas.

As seen in Table 7, 94 per cent $(n=81)$ of the respondents indicated that from their experience they perceive that simulation is an effective tool for evaluating competency in residual skills competency areas. Six per cent $(n=81)$ of the respondents indicated that from their experience they believe simulation is not an effective tool for evaluation in residual skills 
competency areas. These results show that simulation is a valuable replacement tool that can be used at tertiary level for skill development in management accounting areas.

\section{Perception of the sufficiency of using simulation as an evaluation tool}

As seen in Table 7, the participating training officers were asked whether they consider simulation to be a sufficient tool, in other words the only tool that does not have to be combined with other forms of evaluation, to use in the evaluation of whether a trainee has basic experience in residual skills competency areas. To this question, 83 per cent $(n=83)$ of the respondents responded that from their experience they believe that simulation is a sufficient tool for evaluation purposes. Seventeen per cent $(n=83)$ of the respondents indicated that from their experience they believe simulation is not a sufficient tool for evaluation purposes. These results show that simulation is a sufficient tool that can be used at tertiary level for skill development in management accounting areas.

For the above respondents who indicated that simulation is a sufficient tool to use, the questionnaire furthered enquired whether they believe that one simulation is sufficient or whether they are of the opinion that more than one simulation would be required to conclude on whether a trainee is competent in the relevant skills competency area. As seen in Table 7, 36 per cent $(n=77)$ of the respondents indicated that one simulation is sufficient, while 64 per cent $(n=77)$ were of the opinion that when simulation is used, more than one simulation are required to conclude on the competency of a trainee in a skills competency area. A highly significant portion of training officers of medium-sized training offices $(69.23 \%$ with $p>0.05$ and Chi-square $(\mathrm{df}=2)$ of 7.07$)$ indicated that they are of the opinion that one simulation is sufficient; however, only an insignificant 29.51 per cent $(p<0.05)$ of smaller firms indicated that one simulation is sufficient. Training officers of medium-sized training office auditing firms are therefore more willing to accept one simulation as sufficient than training officers of smaller firms.

\section{CONCLUSION}

University students in South Africa wanting to become CAs are required to have a SAICA accredited qualification as well as practical exposure in various competency areas, as required by the SAICA training programme. Training office auditing firms in South Africa make use of a combination of practical exposure, in-house simulation or simulation presented by external service providers to provide exposure in management accounting competency areas to their trainees.

The first objective of this study was to determine to what degree training office auditing 
firms in South Africa provide practical exposure to their trainees in the field of management accounting in order to identify a gap in practical exposure that ought to be dealt with at tertiary level. It was found that large, medium-sized and small training office auditing firms provide practical exposure in analysing an entity's financial situation and evaluating an entity's current working capital position to a large extent, as 50 per cent or more training officers indicated that practical exposure is available. This can be expected due to financial analysis also being a form of auditing procedures performed in practice (ISA 2010). Exposure in the evaluation of the financial implications of investment decisions and business valuations is limited in large, medium-sized and small firms. This is supported by literature stating that the main focus of trainees at auditing firms is auditing (Joubert, Coetzee and Oberholzer 2009) and that these two skills are not normal skills required to do a normal audit (SAICA 2016c). This creates the opportunity for universities to introduce skills development in these areas at tertiary level. Large firms also provide practical exposure in management decision-making and control outcomes to a larger extent than medium-sized and small firms. This might be due to larger firms having broader client bases with greater exposure to complex transactions (Van Romburgh and Van der Merwe 2015). Larger firms also provide trainees with exposure in and knowledge of how businesses operate (Joubert, Coetzee and Oberholzer 2009).

The second objective of this study was to determine to what degree training office auditing firms in South Africa make use of workplace simulation (either in-house or outsourced) to evaluate competency in management accounting skill areas. It was found that simulation is actively used by the training office auditing firms of the training officers that took part in this study in the evaluation of management accounting competency areas. This was expected due to the nature of auditing firms being auditing- and assurance-driven (Joubert, Coetzee and Oberholzer 2009). Larger firms in this study generally use simulation to a lesser extent than medium-sized and small firms, where practical exposure is more limited. Large, medium-sized and small firms all make use of simulation to a large extent when evaluating competency in the evaluation of financial implications of investment decisions and business valuations. It was also found that the size of the firm has a significant impact on the way in which competency is evaluated in the monitoring of cash flow. Larger firms tend to make use of simulation more than smaller firms in this area. This is expected in smaller firms, as trainees at smaller firms are exposed to a client's entire business, in other words including cash flow management, and not only to specialised areas (Joubert, Coetzee and Oberholzer 2009). Larger and medium-sized firms also tend to make use of in-house simulation when evaluating competency in the evaluation of financial implications of investment decisions and business valuations, where-as smaller firms tend to make more use of outsourced simulation. This is supported by literature 
indicating that larger firms provide trainees with exposure across a wider range of industries (Joubert, Coetzee and Oberholzer 2009) and as a result larger firms might be able to better provide in-house simulation to their trainees, as they have some form of client base exposure in those fields. These results show that simulation is a valuable teaching tool that can also be used by universities at tertiary level for skill development in management accounting areas.

The third objective of this study was to determine whether training officers perceive simulation to be effective and sufficient to use in providing basic exposure to their trainees. A total of 94 per cent of the auditing training officers that took part in this study perceive that making use of simulation as a tool to evaluate whether trainees are competent in management accounting residual skills competency areas is effective. A total of 83 per cent of the participating training officers also perceive that using only simulation as an evaluation tool regarding a management accounting residual skills level is sufficient; however, a highly significant number of training officers $(64 \%)$ believe that evaluation should be based on more than one simulation to conclude on the level of competency. These results show that simulation is a sufficient teaching tool that can also be used by universities at tertiary level for skill development in management accounting areas.

The empirical results of this study, namely that simulation is perceived by training officers to be effective in the evaluation of competency in management accounting skill areas, are supported by the literature as both Van der Merwe (2013) and Viviers et al. (2016) found simulation to be invaluable to learning.

In conclusion, practical exposure to management accounting competency skill areas is limited and simulation is widely used to evaluate competency in these areas. Based on the perceptions of training officers, it is suggested that simulation be used in areas where practical exposure is limited and creates the opportunity for universities to address the practical exposure gap at tertiary level. It is further recommended that more than one simulation be used to test competency and that SAICA includes this as a requirement in its training and learning regulations.

\section{LIMITATIONS OF THE STUDY}

It is recognised that this study was based on data received directly from a low number of training officers in South Africa and that the results only reflect the perceptions of these training officers and can therefore not be generalised to the entire population. The view of trainees or recently qualified accountants were not obtained and might lead to different perceptions. The sample was based on a 95 per cent level of confidence and a 10 per cent margin of error. However, the results still provide information on how the practical exposure gap is addressed by a relatively 
large number of trainees in South Africa (2 211 out of 8902 trainees) and may be valuable to universities and SAICA that wishes to address the practical exposure gap. A similar limitation was applicable in other studies (Barac 2009; Coetzee and Oberholzer 2009; Van Romburgh and Van der Merwe 2015). Several steps were followed to decrease the effect of non-response bias:

- Follow-up e-mails to non-responding training officers were sent four times after, which the response rate increased every time.

- Training officers were encouraged to complete the questionnaire by offering each participant the final anonymous results of this study.

- All training officers from all different entity sizes were given the opportunity to take part in the study and answer the questionnaires. Respondents came from all spectrums, namely small, medium-sized and large firms.

- $\quad$ Training officers from all nine provinces were also given the opportunity to take part in this study. As a result, the respondents represented all nine provinces.

\section{AREAS FOR FURTHER RESEARCH}

Thirty-nine per cent of training officers of training office auditing firms that took part in this study indicated that they perceive simulation not to be an effective tool to use in the evaluation of whether a trainee has advanced experience in compulsory or elective skills competency areas. Further research could be done in future studies to determine the extent to which simulation is used to evaluate competency in compulsory or elective skills areas and identify other practical exposure gaps that could be addressed by universities at tertiary level. Further research could also be done in this area by surveying students studying towards becoming CA(SA)'s and auditing trainees of training office auditing firms to obtain their perspective on the use of simulation to evaluate competency.

\section{REFERENCES}

Barac, K. 2009. South African training officers' perceptions of the knowledge and skills requirements of entry-level trainee accountants. Meditari Accountancy Research 17(2): 19-46.

Barac, K. and L. Plessis. 2014. Teaching pervasive skills to South African accounting students. Southern African Business Review 18(1): 53-79.

Chartered Accountants ANZ. 2015. Mentor practical experience guidelines. 2015. http://www.chartered accountants.com.au/Candidates/The-Chartered-Accountants-Program/Practical-experience/ Mentors

Chartered Professional Accountants of Canada. 2014. The UFE candidates' competency map. 2014. https://www.cpacanada.ca/ /media/site/cica resources/ufe_candidates_competency_map

Coetzee, Stephen and Ruanda Oberholzer. 2009. The tax knowledge of South African trainee 
accountants: A survey of the perceptions of training officers in public practice. Accounting Education 18(2015): 421-441.

CPA see Chartered Professional Accountants of Canada.

De Villiers, R. R. 2015. Evaluating the effectiveness of a newly developed simulation in improving the competence of audit students. (Doctoral dissertation). https://dspace.nwu.ac.za/handle/ $10394 / 15165$

Dellaportas, Steven and Trevor Hassall. 2013. Experiential learning in Accounting Education: A prison visit. The British Accounting Review 45(1): 24-36. Elsevier Ltd.

Francis, Graham and Clare Minchington. 1999. Quantitative skills: Is there an expectation gap between the education and practice of management accountants? Accounting Education 8(4): 301-319.

ICAS. 2016. ICAS The professional body of CAs. 2016. https://www.icas.com/education-andqualifications/how-to-become-a-chartered-accountant-ca

IFAC. 2007. International education practice statement. 2007. http://www.javeriana.edu.co/ personales/hbermude/areacontable/particulares/IEPS_3_Practical_Experience_RequirementsIntial_Professional_Developments_for_Professional_Accountants.pdf

ISA. 2010. International Standard on Auditing 520: Analytical procedures. International Standards on Auditing. 2010. http://www.ifac.org/system/files/downloads/a026-2010-iaasb-handbook-isa520.pdf

Joubert, B., S. Coetzee and R. Oberholzer. 2009. Tax topics a trainee Chartered Accountant should be taught: A survey of perceptions in and outside public practice. Meditari Accountancy Research 17(1): 14-31.

Keevy, Monique. 2016. Using case studies to transfer soft skills (Also known as pervasive skills): Empirical evidence. Meditari Accountancy Research 24(3): 458-474.

Lincoln University. 2006. Sample size. In Student Learning Centre. https://ibrary2.lincoln.ac.nz/ documents/Sample-size.pdf

Lu, Jiafang, Philip Hallinger and Parinya Showanasai. 2014. Simulation-based learning in management education. Journal of Management Development 33(3): 218-244.

Rudman, R. J. 2013. A new approach to making management accounting practical. In 5th International Conference on Education and New Learning Technologies, 1836-1847. https://library. iated.org/view/RUDMAN2013ANE

Rudman, R. J. and W. Kruger. 2014. Using a group work project as an educational tool in Management Accounting education. The International Business \& Economics Research Journal (Online) 13(3): 611-628.

Rudman, R. J. and J. Terblanche. 2012. The perceived advantage of work experience as a learning tool for university auditing students.pdf. Southern African Journal of Accountability and Auditing Research 13(May 1992): 57-71.

SAICA. 2015a. SAICA training programme - prescribed competencies. 2015. https://www.saica.co.za/ Portals/0/Trainees/documents/SAICA_Training_Programme_Competencies_2016.pdf.

SAICA. 2015b. Simulations in the CA (SA) Training Programme - What? Why? When ? How ? 2015. https://www.saica.co.za/Portals/0/Trainees/documents/Requirements_for_Simulations_Updated_ Sep2015.pdf.

SAICA. 2016a. Becoming a CA. 2016. https://www.saica.co.za/Training/BecomingaCA/tabid/ 157/language/en-US/Default.aspx

SAICA. 2016b. SAICA Training Programme Implementation Guide. 2016. https://www.saica.co.za/ Members/TheCA2010TrainingProgramme/tabid/1686/language/en-US/Default.aspx

SAICA. 2016c. SAICA Training Regulations. 2016. https://www.saica.co.za/Portals/0/Trainees/ documents/1_January_2016.pdf

SAICA. 2017. Becoming a CA. 2017. https://www.saica.co.za/Training/BecomingaCA/tabid/157/ 
language/en-US/Default.aspx

Schutte, Danie. 2013. Towards a competency framework for SME Accountants - A South African perspective. Global Journal of Management and Business Research Accounting and Auditing $13(5)$

Steenkamp, L. P. and S. P. J. von Wielligh. 2011. The perceptions of trainee accountants of the usefulness of an audit simulation at university level. Southern African Journal of Accountability and Auditing Research 11: 9-21.

Van der Merwe, Nico. 2013. An evaluation of an integrated case study and business simulation to develop professional skills in South African accountancy students. International Business \& Ecinomics Research Journal 12(10): 1137-1156.

Van Romburgh, Henriëtte and Nico van der Merwe. 2015. University versus practice: A pilot study to identify skills shortages that exist in first-year trainee accountants in South Africa. Industry and Higher Education 29(2): 141-149.

Viviers, H. A., J. P. Fouché and G. M. Reitsma. 2016. Developing soft skills (Also known as pervasive skills) - Usefulness of an educational game. Meditari Accountancy Research 24(3): 386-389.

Warffemius, P., L. Kruger and G. Steenkamp. 2015. SAICA'S Academic Traineeship Programme: Would guidelines facilitate focused skills development? Journal of Economic and Financial Sciences 8(2): 354-371.

Wellington, William J., A. J. Faria, David Hutchinson and Maureen Gowing. 2011. An interdisciplinary study of the impact of playing a marketing simulation game on student knowledge of management accounting/finance principles. Developments in Business Simulation and Experiential Learning 38: $320-26$. 